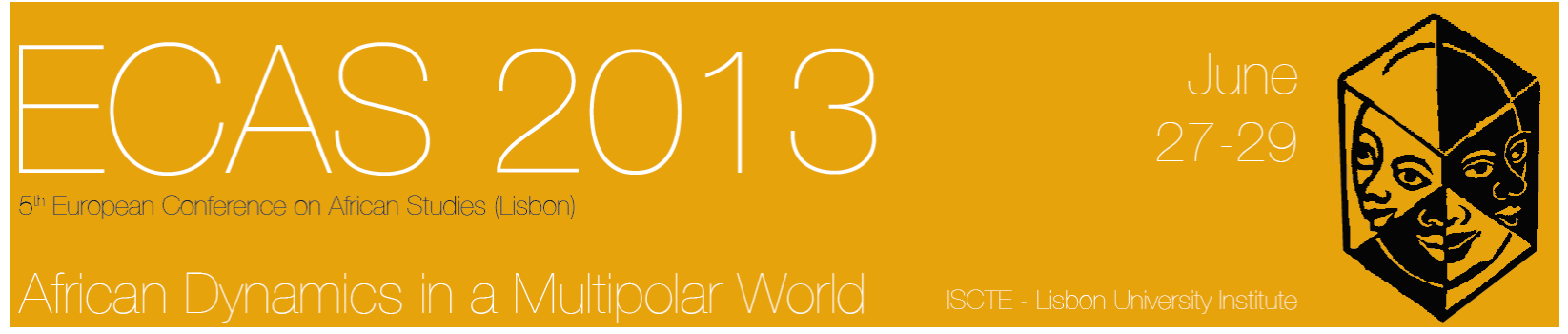

\title{
ECAS 2013
}

$5^{\text {th }}$ European Conference on African Studies

African Dynamics in a Multipolar World

(C)2014 Centro de Estudos Internacionais do Instituto Universitário de Lisboa (ISCTE-IUL)

ISBN: 978-989-732-364-5

\section{DO TRANSNATIONAL LINKS MATTER AFTER RETURN? LABOUR}

MARKET PARTICIPATION AMONG GHANAIAN RETURN MIGRANTS.

\author{
Mary Boatemaa Setrana \\ Centre for Migration Studies \\ University of Ghana \\ Legon -Accra, Ghana- West Africa \\ mobkjowat@yahoo.com
}

Steve Tonah

Department of Sociology

University of Ghana

Legon- Accra, Ghana- West Africa

tonah@operamail.com 


\begin{abstract}
Previous studies on transnationalism have looked at 'remittances' and 'short-term visits' to the home community and its transformational impact. However, little attention has been given to how transnational links enable return migrants to economically reintegrate into the home community. Although transnationalism describes return migration as a circular movement, there is still evidence of permanent return. Using Ghana as an example, this paper examines the conditions, strategies, assets and labour participation of return migrants. The study employed both qualitative and quantitative methods in investigating its set objectives. The study found that for wage employed returnees, maintaining professional contacts abroad is a key factor in ensuring their sustenance in the local and global job market. On the other hand, having investments abroad is important for self-employed returnees to sustain their return. The paper suggests that in order to promote national development and enhance national competitiveness in a globalizing world, Ghana needs to strengthen both its educational and business sectors. With this goal in mind, Ghana needs to encourage collaboration amongst its residents abroad and encourage opportunities for the sharing of knowledge and expertise.
\end{abstract}

Keywords: transnational, return migration, Ghana, wage employed, self-employed, labour market 


\section{Introduction}

Transnational activities of immigrants in Western countries have received more attention than migrants' post-return activities in their home countries. This was not surprising, until recently, return migration had been under researched in the migration literature. The increasing significance of the return movement led to the first European conference on international return migration, held in Rome in 1981 (Kubat, 1981). Following this, Wyman (2005: 16), citing some fascinating return migration statistics, noted that at least one-third of the 52 million Europeans who left Europe between 1824 and 1924 returned permanently to their homelands. Similarly, the return rate was even greater in the USA in 1931 due to the economic recession: 89,000 left the USA compared with only 43,000 immigrants who arrived. Most likely, some of these immigrants found their way into Latin America and the African continent. Despite a lack of adequate data, migration from West African countries is also known to be essentially temporal (Adepoju, 2005; $\mathrm{Ba}, 2006$ ) due to restrictive immigration policies that have led to a greater emphasis on (forced or voluntary) return as a policy tool or aim (see also Black and Gent 2004; Blitz et al. 2005; Koser and Black 1999).

Such restrictive policies in host countries have deepened the transnational lives of migrants, and for that matter Ghanaian migrants abroad, in the sense that their ties and obligations occur in both host and their country of residence (Orozco, 2005). Migrants' attachment to the homeland is overly manifested through transnational practices such as remittances, phone calls and visits, among others (Nuro, 1999). Ghana's central bank reported $\$ 1.6$ billion in remittance inflows in 2009. These remittances are usually used for physical projects, particularly businesses, housing, as well as household consumption (Anarfi, Kwankye and Ahiadeke, 2005; Lothar, 2007). Focusing on activities of migrants abroad has hardly 
provided a bilateral perspective on the concept of transnationalism. This is striking because the lives of migrants in the countries of origin are also likely to become 'trans nationalised' and it would be unrealistic to assume that migrants would readily 'give up' their transnational activities and links after return.

In this article, our aim is to fill part of the gap in the literature on transnationalism by studying the benefits of transnational links to Ghanaian return migrants. First, the paper provides an overview of transnational businesses of Ghanaian migrants abroad. This is followed by a theoretical perspective on transnational approach to return migration. Then, there is a presentation of the methods used in the study and a description and analyses on labour market participation among return migrants. Finally, this paper ends with a conclusion and recommendation.

\section{The Context: Transnational Influence on Migrant businesses in Ghana}

Many of the small businesses in Ghana today have visible links with foreign places, sometimes in their names, but more often, in the products they sell and the services they offer. These businesses range from second hand goods such as cars, fridges and clothes, to new Italian floor tiles, fashion items, and internet services (Smith, 2007). Besides businesses with clearly visible links abroad, there are many others initiated or supported by migrants. It is generally acknowledged that much of the flow of remittances by migrants to the country of origin, whether channelled through formal or informal avenues, is meant for businesses (see de Haas, 2003; Hamann, 2000). Mazzucato et al (2005) have indicated with respect to Ghanaian migrants in Amsterdam that, 28 per cent $(28 \%)$ of all remittances were invested in businesses in Ghana, mainly in Accra and Kumasi. According to Asiedu (2005), Diko and Tipple (1992), unskilled 
Ghanaians migrate abroad primarily to save capital in order to invest in houses and businesses in Ghana, since opportunities to accumulate such funds in Ghana are limited. Asiedu (2005) goes on to claim that a direct relationship exists between the duration of migrants stay abroad and their ability to accumulate enough savings for housing and business projects in Ghana. The contribution of remittances to the local economy through business investments is increasingly recognized and welcomed, as these remittances are regarded as being 'production' oriented. However, what is not clear in these studies that analyse remittances and businesses is how migrants sustain their businesses upon return.

At present, there are two debates on migrants and their role in business related activities in the economy of Ghana. The first debate looks at the migration-development nexus. It is concerned with the productive use of savings by migrants, such as investments in businesses, rather than in consumption activities like the purchase of cars, the building of mansions, or funding lavish ceremonies such as funerals (Black, King and Tiemoko, 2003). The second debate concerns the sustainability of migrants' business investments and their contribution to the national economy. In this debate it is argued that larger businesses, rather than smaller sole proprietor businesses, can help expand Ghana's economy. These two debates interrelate in examining the support that migrant investments contribute to Ghana's economy, and how they alleviate rural and urban poverty and boost other sectors of the economy, particularly agriculture. Central to both debates is the view that current investments of migrants in businesses are insufficiently innovative. This, it is argued, relates to the unwillingness of migrants to place their hard-earned savings in investments believed to carry risk. These risks might arise if migrants were to pursue new, uncharted niches in the economy, or if they were to partner others in business ventures, pooling capital to establish more capital-intensive businesses. Meanwhile, 
another way by which migrants could escape these risks is to manage their own business upon return and also give it a transnational face.

The unwillingness of migrants to take such steps is because they see few other possibilities to make a living in Ghana (Ammassari, 2004; Black, King and Tiemoko, 2003). While these two debates do raise relevant points, this paper argues that they give insufficient acknowledgement to the efforts migrants make in their bid to sustain their businesses in the national economy.

\section{Transnational approach on return migration}

Until recently, migration was understood in terms of two opposing outcomes: permanent settlement abroad or permanent return home. Return migration especially was thought of as the final outcome of the migration process. This relatively static bipolar model is a simplistic and unilinear depiction of migration and return migration which is not consistent with the realities of population movements in an increasingly transnational and interconnected world. Transnationalism refers to the multiple ties and interactions that link people and their institutions across the borders of nation-states (Vertovec, 2009). These kinds of strands are built on reciprocity and trust.

The transnational emphasis in migration studies is based upon the recognition that modern migration and settlement patterns are increasingly taking place within bipolar and multipolar structures. This behaviour, which was probably not part of early forms of migration, characterises modern patterns of movements. Some authors argue that migrants may not return definitely to their country of origin or their parents' birthplace; they may still maintain various forms of linkages with it which could develop into eventual return for permanent settlement 
(Thomas-Hope, 1999). On the other hand, it could further be argued that even when migrants have returned permanently to their parent's birthplace, they may still maintain various forms of linkages with the host country.

This new theoretical approach is an attempt to go beyond traditional migration theory and the structural approaches, 'informed by and developed in service of the nation-state ... treated migrants as individuals who either departed (emigrants) or arrived (immigrants),' (Levitt and Nyberg-Sørensen, 2004). It criticises the notion of space which assumes that physical, social and political spaces perfectly coincide with a geographical space which is radicalised within the boundaries of a nation-state (Jackson et al., 2004). Within this line of thought, the social fields approach proposed by Peggy Levitt and Nina G. Schiller (2004: 2), explains that individuals belonging to transnational social fields 'are through their everyday activities and relationships, influenced by multiple sets of laws and institutions. These sets of regulations could make it difficult for return migrants to easily give up their transnational activities and practices even after permanent return. Their daily rhythms and activities respond not only to more than one state simultaneously, but also to social institutions, such as religious groups, that exist within many states and across their borders.' Therefore, through the transnational approach we are able to understand that immigrants live between the home and the host country and they influence, and are in turn influenced by what goes on in these two places. In this regard, return migrants may not have strong ties with the host country and may exercise their double-citizenship rights to maintain contacts with the host country. For instance, some return migrants may receive pension pays from their host countries even while in the home country. In this regard, a transnational approach helps us understand return migrants as individuals whose activities in the home country are affected by host country activities as well (Levitt and Nyberg-Sørensen, 2004). 


\section{Research Methods and Profile of Study Population}

Ghana, like most African countries, has no universal registration of returnees on which to base a random sample. However, Anarfi (2003) found that returnees largely mirrored national demographics overall and thus, an effort was made in this study to find a balanced sample with regard to age and sex. The study also improved on the quality of work by purposively selecting four sites; namely, Accra and Kumasi metropolitan areas and Dormaa/Berekum and New Juaben municipal areas. The international migration literature (see Anarfi et al., 2000; Taylor, 2009) cites these locations as the established migration flow regions in Ghana.

The study used the snowball technique in selecting its respondents, which has advantages and setbacks. In order to have as much diverse responses as possible, key informants with in depth knowledge of the survey areas were recruited to assist the researcher to identify returnees. During the preliminary field trip to the selected sites, 14 returnees were selected. Through chain referrals by the 14 respondents and personal contacts, the researcher finally achieved its required sample size. A total of one hundred and thirty eight (138) return migrants from Western countries were invited to participate through personal contacts and telephone calls. However, the difficulty and sensitivity of the research only made it possible for 120 respondents to actually participate.

The first section of the survey asked questions relating to migrants socio-economic circumstances before and after return. The survey instrument was pre-tested to help establish stability, consistency and content validity of the questionnaire. It was self administered and the advantage was that all questions which were relevant to respondents were answered. At the end of the structured questionnaires, respondents were asked to give their consent by providing their contact details for further in depth interviews. Twenty-five of such respondents were selected 
based on their sex, age and mode of return. The qualitative information focused primarily on post-return experiences and was a follow-up on the structured questionnaires.

Seventy-eight percent (78\%) of the respondents were between the ages of 30 and 54 , including some younger and older returnees. A little less than half of the respondents were females (about 38\%). A representative ethnic mix was a more difficult task because of the diverse groups as well as the absence of records on ethnicity of emigrants or returnees. Most of the respondents were within their productive ages (with an average age of 42 years) with males dominating (63\%). Their educational level was generally high with 61 per cent having either university or diploma certificate. Out of the total of 120 respondents, 54 per cent either furthered their education or acquired some kind of training or skills abroad. Respondents were found in all sectors of the Ghanaian labour market with majority (23\%) of the skilled returnees in the educational sector as lecturers, researchers and high school teachers. Other skilled returnees worked in the banking, administration, sales/marketing and health sectors. This is attributed to the fact that recent recruitment of skilled personnel appears limited to the teaching and telecommunication sectors as well as some non-governmental organisations (cf. Anarfi and Jagare 2005). Most of the low or unskilled returnees were engaged in trading/businesses (29\%) including, mechanics, drivers, traders, masons, hairdressers and tailors. Eight percent (8\%) were farmers while 5 per cent had no income earning activity. More than half $(69 \%)$ of the respondents were married, while the rest were either single (22\%), separated or divorced $(8 \%)$ or widowed $(1 \%)$. About 89 per cent returned voluntarily while 11 per cent were involuntary ${ }^{251}$ return migrants.

\footnotetext{
${ }^{251}$. The situation of the involuntary returnees were not discussed in the paper because their number is too small for any statistical analysis.
} 
The return migrants had stayed in different countries in Europe and North America with majority coming from the United Kingdom (41\%). This could be due to the common language and similar educational systems of Ghana and Britain (a former colonial master of Ghana). The average time spent abroad was about nine years with a minimum of one year and a maximum of 44 years. Majority of the return migrants came back home because they either felt homesick (32\%); had completed their training or ended their contract abroad (21\%); wanted to start their own businesses or projects (15\%); or had lost their jobs in the host country (8\%).

\section{Labour Market Participation among Return Migrants}

In terms of accessing the job market in Ghana, return migrants could be categorised into two. The first category consist of return migrants in wage employment with mostly higher education and professional qualifications working in the public or private formal sectors. These include doctors, nurses, lecturers, teachers, engineers and bankers. A little more than half (52\%) of the return migrants interviewed were found in this sector. The second consist of self-employed return migrants who came to Ghana with capital, but mainly have secondary education; they are either in the private formal or informal sector. About 44 per cent of the respondents are in this area of employment. These enterprises include schools, farms, beauty salons, and building materials and groceries stores. Only six respondents (about 3\%) had no income earning activity as at the time of the survey.

Despite all the preparations made towards their return, most respondents indicated that it took some time to enter the Ghanaian labour market. Majority (78\%) of the respondents had their jobs within three months of return while approximately, 22 per cent had jobs after three months 
and beyond. Most of the respondents who took more than three months in finding jobs were usually those searching for wage employment. In cases where the job search took more than a year, respondents relied on their savings while others depended on extended families, both home and abroad, to support them financially. On the other hand, respondents who took a longer time than expected to find jobs later became a burden on their families.

Family members and relatives play a crucial role in the economic behaviour and business ventures of return migrants (Tiemoko, 2004; Black et al., 2003). Having been away for a number of years, the study revealed that kinship and social networks did not only become the main source of information for return migrants but were also used to establish the needed acquaintances required to secure employment in the formal sector. These networks comprised of those who had the capacity to influence their recruitments as well those who served only as informants. About 62 per cent of the respondents secured or started their jobs with the help of friends, relatives, schoolmates, church members and associations while 29 per cent either responded to an advert or sent an application and 9 per cent returned to their former jobs. Presented below is the experience of one of the respondents re-entering the employment market:

Emma, a Master's degree holder, secured his first job with an insurance company in 2007, two years after he returned to Ghana. He obtained this job with the assistance of his uncle who had copies of his curriculum vitae. Although news of a new job is received with joy, it did not come with all the expectations of Emma because he was employed based on his Bachelors certificate. In order to overcome the stigma attached to being 'unemployed', he accepted the offer and kept on searching, making use of all available networks. Among several applications, he had also applied to a University for the Position of an Assistant Registrar. Emma was invited for an interview in 2008 after which he was employed by the University as an Assistant Registrar. He stated; I will forever be grateful to my uncle and my friend who helped me to secure jobs in Ghana (Emma, interview in Kumasi, 14 ${ }^{\text {th }}$ December 2011). 
Another respondent shared her experience, thus:

I saw it as a responsibility because some friends had helped me before and were definitely going to continue assisting me on my return, so I needed to appreciate them. My mother was always asking me to buy gifts for this and that person; she never ceased reminding me of the assistance I received from friends and family. Mantaining contact with friends and family through internet and telephones increased the bond between us. I remember upon my return, my former director whom I used to call on phone while abroad, helped me re-enter the Ghana Education Service(Akua, interview in Accra, 22nd January, 2012).

These social kin and friendship networks are maintained by returnees through transnational practices while abroad. They enable returnees to secure jobs that would have been difficult to acquire because they had to compete with non-migrants for the limited available vacancies. Here, the use of networks offers explanation beyond migrant businesses. Returnees in wage employment also used the help of their networks to secure work in the formal sector. Therefore, social networks which were maintained while abroad are relevant not only to those who want to start their own businesses but also to those who want to find formal jobs in the private and public sectors.

Another significant observation was the willingness of some respondents to work in areas below their educational qualification or in professions they were less enthusiastic in. For some respondents, accepting such offers irrespective of the education and skills they had acquired abroad were the only options available because of the challenges in the labour market.

Some migrants were faced with language problems on their return. For example, in depth interviews with some doctors from Russia showed that, on return, language was a barrier. They could not translate the names of the hospital equipment from Russian into English. This delayed service delivery at the hospital wards. However, with time they learnt these from friends and 
other colleagues who had similar experiences. This kind of language challenge emanated from the fact that returnees had spent their entire higher educational life in Russia. Therefore returning to their motherland where the official language is different, posed a conflicting identity which they had to readjust to in order to function adequately (Cassarino, 2004).

The other category is self-employed returnees who utilised their networks at home and accumulated resources to set up their private enterprises. Self-employed returnees expressed different reasons for starting their own businesses. These include the need to create employment opportunities, the love for the work and the need to be independent and build a fortune for their children. Indeed, the reasons outlined by returnees hardly support the view that migrants are often entrepreneurial by default rather than choice. In other words, return migrants started their own businesses based on their personal aspirations and attitudes and not because they saw fewer other possibilities to make a living in Ghana (Ammassari, 2004; Black, King and Tiemoko 2003).

Most of the self-employed returnees hired stores in the city centre where commercial activities are vibrant. Some respondents came along with capital goods such as electronic machines, corn mills, building materials, computers and cars that aided their businesses. Nana, for example, sold his corn mill in order to start his mattress selling business, she explained further:

I decided to start my shop in Accra but the rent was so expensive. I came back to Kumasi, surveyed the town very well and I began a mattress shop. Before starting the shop, I sold one of the corn mills and used the capital to start my own business. I was able to buy a lot of mattresses to start the shop. It was moving on very well which made people venture into that business too (Nana, interview in Kumasi, $28^{\text {th }}$ December 2011). 


\section{Benefits of Transnational Links on employment after return}

Although the rise of academic and policy concern with transnationalism might imply that permanent return is becoming less relevant as a process, not just in relation to Africa, transnationalism itself can arguably be conceptualised as a form of return, just as it can be seen as a form of integration in host societies (Kivisto, 2001). Thus, contrary to the perspective of northern governments, where any return that involves re-emigration is seen as indicating a failure of the sustainability of return (cf. International Organization for Migration, 2003), an alternative view suggests that in order for their return to be sustainable, returnees need to retain continued access to the wider international professional and social world in which they have worked and lived. This is reflected in the way in which these respondents continue to value their contacts made abroad after their return. The experience of Junior is related below:

Junior, a young nurse migrated out of Ghana in 1992 to the UK where he pursued further education as a medical doctor. He said, his dream in life was to become a doctor but because he was from a poor home, his parents could not pay for him to live up to his dream. After some years of practising nursing in a small village in Ghana, he earned a government scholarship to study abroad and subsequently, he diverted from nursing to study medicine. While away, he had the opportunity to specialise in pathology and also work with one of the renowned hospitals in the UK. By dint of hard work, he received favour from his employers and colleagues. Therefore, since he returned to Ghana in 2005, he is sometimes called upon by his previous employers abroad for assistance especially during summer breaks. He confirmed that the intermittent call for support gives him the opportunity to earn some more income as well as learn new skills in his area of specialisation. He currently works at the Korle-Bu Teaching Hospital in Ghana as the head of his department. He is a member of the Association of Clinical Pathologist in UK.

Junior kept close contact with colleagues and previous employers even after his return to Ghana. He communicates with his colleagues in the UK via emails and sometimes phone calls. He also links them up when he faces difficulties in his job to see if they have any assistance. He is also called upon for support in his area of speciality when his colleagues abroad also need his assistance (Junior, interview in Accra, $3^{\text {rd }}$ December 2011). 
Forty-nine percent (49\%) (that is, 50 out of 120 respondents) of the returnees said they had professional contacts abroad. In all of these cases the relationships were built by the individuals themselves. Some returnees, like as Junior, did not give up on their contacts abroad; they maintained contacts and exchanges with their foreign partners through the internet, video link and other social media, telecommunication among others. Their professional contacts are so crucial to them that they have become part of their everyday lives in the home country. Doctors, lecturers and engineers who find themselves among such networks typically spend their sabbatical in hospitals and schools abroad. To them, such visits help them to keep abreast with the new trends and modern technology in their jobs while at the same time boosting their incomes back home. It further enhances the ability of return migrants to compete with nonmigrants for the opportunities availabile in the Ghanaian labour market because of the belief that people who are trained abroad have good work ethics and are smarter. Due to such beliefs, wage employed returnees claimed they were favoured at job interviews. Most of the returnees interviewed had thus gone beyond the nation states and are now living in transnational spaces where they access skills and knowledge for the benefit of both the home and host countries.

About half (51\%) of the returnees who are self-employed have business contacts abroad. Although some admitted that these business contacts were not too close, they still depend on them whenever there was the need for it. Some of the self-employed return migrants were also involved in the sale of imported items and 'second hand"252 goods such as TVs, cooking utensils, tea cups and mattresses. Some of the respondents attested to the fact that their businesses were

Slightly used items imported from Europe and North America 
booming compared to other non-migrant businesses because many Ghanaians hold the belief that overseas goods are durable even when they are slightly used.

Returnees usually obtain their goods on credit basis from their partners abroad. They then 'sell them and pay for the goods in full after sales or share profit with business partners' depending on the nature of the contract. Partners contract businesses informally on two main levels; first, the return migrant pay for the goods before they are sent to Ghana and second, the partner abroad send down the goods for the return migrant to make payment for them after sales. These informal arrangements changed overtime. In this case, respondents are making use of their links abroad to keep their businesses running and also to earn a living for themselves and their families. Kweku has a business partner who supplies him with computers from the Netherlands; He said:

My former colleague in the Netherlands has been supplying me with these computers. I go to the harbour almost every three months to retrieve the goods for the shop. The deal is that, he brings them so that I pay for them after sales. The initial plan was to just sell computers but gradually I had to also include servicing because people kept bringing their broken computers for repairs. As we speak now all these guys are my apprentice [pointing to some four guys who were busy working on some of the computers], I have trained them for that (Kweku, interview in Kumasi, $6^{\text {th }}$ January, 2012).

Return migrants explained that in order to sustain their position in the transnational arena, they needed to engage partners who were most likely to help them sustain their businesses or association. For this reason, returnees identified trust as a key factor in maintaining these links. Smith (2007) in studying transnational businesses among Ghanaians in the urban sector also identified trust as an important factor. Indeed, among these return migrants, there were hardly any formalised agreements in their transnational arrangements. Return migrants engaged in these activities rely on information collected through family and friends in the selection of their 
business partners. However, return migrants also claimed that they were aware of the risks involved in these kinds of transnational arrangements; for example, other party(ies) may not fulfil their part of the arrangement. For example, one of the interviewees who trade in secondhand refrigerators shared this thought:

Business is business, it has ups and downs, but so far, my partner and I have been faithful to each other. Since I have been diligent in my sales and sharing of the profit, I don't forsee any breach of contract. We both benefit from the business so why would one cheat on the other (Mr. Amofa, interview in Koforidua, 25th October, 2011).

In this regard, Lyon, (2000: 664-665) argues that trust operates when there is confidence in other agents, despite the uncertainties, risks and the possibility for them to act opportunistically. Contrary to Lyon's arguement, these respondents said, they hardly foresee such risks because they are confident in their partners so long as they - the return migrants, fulfilled their part of the arrangement. This means also that the multiple ties and interactions that link people across the borders of nation states (Vertovec, 2009) could only be successful if it is built on trust and reciprocity.

Other return migrants received financial support from relatives both home and abroad to keep their businesses running. Derrick, for instance, had no initial capital to start business upon return. Actually, he returned to Ghana because he had lost his job in Italy. Adding on, Derrick only had a secondary school certificate which could not find him a well paid job in Ghana. In order to make a living, his eldest sister who also lives abroad with her family assisted him to start an electrical shop. Derrick's case, further emphases earlier studies that found migration to be a means to "migrate" out of poverty (Anarfi et al, 2003; IOM, 2009). 
Apart from professional and business contacts, about 22 per cent of the respondents also had investments abroad. The investments include mortgage(s), bank savings, shops and pension pays among others. Some respondents said that they deliberately kept those investments to support them financially since they perceived the Ghanaian economy to have several challenges. Therefore, to sail through these challenges they maintained some links abroad that could assist them financially until they had established themselves back home. Paul shares his story about receiving his pension pay from the UK:

You know, I was on pension before I returned to Ghana to start this school. So my wife has been remitting my pension pay to me every month. When I was coming to Ghana, I gave her my card details so she could send me money from time to time. In fact this school is doing well because of the pension pay. Sometimes parents don't pay school fees and meanwhile teachers need to be paid. In Ghana you can hardly go to the banks for loans because their interest rates are too high (Paul, interview in Kumasi, $23^{\text {rd }}$ January, 2012).

One of the returnees also said:

I have a house in Spain which I gave out for rent before coming to live in Ghana. Every month the occupants deposit the rent in my account. I gave them my bank details before returning to Ghana. At least, for nothing at all, these monthly incomes keep me going in my transport business and also to fulfil other family obligations. You see, I am fulfilled, when I think of the fact that I have a house in Spain that fetches me money every month (Adom, interview in Dormaa, 29th September 2011).

\section{Conclusions and recommendations}

The paper shows that maintaining transnational links after return helps to sustain return migrants in the global labour market through; first, their ability to invest in innovative ideas and skills through the use of their professional contacts overseas; and second, return migrants sustain their businesses by importing goods and services from abroad. These kinds of transnational 
activities give return migrants the opportunity to access resources which might not be readily available in the home country; and also enhance their ability to compete with other businesses in Ghana.

Furthermore, the findings show that return migrants maintain their existence in the transnational space by gaining the trust of their partners. However, the nature of the trust is built informally and over a period of time although return migrants hardly perceive future risks, so long as they fulfil their part of the agreement. In addition, both parties benefit financially from the arrangements. To the returnee, income generated from the business earned him/her a living while to the partner abroad, the income served as an additional income to pay off his expensive bills abroad.

Based on these findings, the paper then concludes that networks maintained through transnational practices while abroad are not only relevant in starting businesses but also in accessing formal jobs in the home country. Our findings support the argument that migrant businesses are maintained by their networks. However, in addition, they also show how returnees use these networks to find jobs in the formal private and public sectors. Again, the decision by returnees to start their own businesses is not by accident as is often portrayed in the literature, rather it is a choice.

Some authors such as Black, King and Tiemoko, 2003 and Ammassari, 2004 have argued that migrant businesses are more often on a small scale and lack innovation because they are for the purposes of sustaining migrants' lives at home. On the contrary, the findings of this study reveal that although some of the businesses were small and for sustenance, they made some crucial impacts in the creation of employment opportunities in Ghana. Finally, the findings support the argument on transnational network formation that suggests that the multi-stranded 
relationships and interactions proposed by transnationalism can only be sustained through trust that could also be established through informal arrangements and relationships.

Following from the above, we therefore make some specific suggestions. First, in order to promote national development and enhance national competitiveness in a globalizing world, Ghana needs to strengthen both its educational and business sectors. With this goal in mind, Ghana needs to encourage collaboration between its citizens and foreign countries and encourage opportunities for the sharing of knowledge and expertise (Aseidu, 2010; Lynn and Salzman, 2005; Hart, 2006). For example, the government should remove barriers and limitations placed on return migrants' and expatriates' travels and also provide subsidies and other forms of assistance to return migrants so that they can work more effectively with their overseas counterparts toward the promotion of national development. In order to enhance such engagements, a database of third-country nationals who left host countries (for example, North America and Europe) at the expiration of their temporary residence or work permit should be created, so that there could be a provision of a long-term multi-entry visas for such return migrants. Alternatively, there could be an understanding that former migrants would be given priority for obtaining tourist or business visas under simplified procedures.

These endeavours call for the strengthening of institutions responsible for the collection and assembling of data on migration such as the Ghana Immigration Service, the Customs Excise and Preventive Service, and the Ministry of Foreign Affairs so that they can provide regular, timely, and comprehensive data to help formulate effective and comprehensive migration policies for the nation. There should also be more effective collaboration with global efforts by the IMF, the World Bank, the OECD, and other UN bodies and institutions to sort out existing 
inadequacies and discrepancies in migration data sets. Furthermore, the impact of investment of return migrants within specific sectors of the Ghanaian economy needs to be evaluated.

\section{References}

Adepoju A. (2005) Migration in West Africa. Paper prepared for the Policy Analysis and Research Programme of the Global Commission on International Migration, Global Commission on International Migration, p. 23.

Ammassari, S. (2004). From Nation-Building to Entrepreneurship: The Impact of Élite Return Migrants in Côte d'Ivoire and Ghana. Population, Space and Place 10(2),133-154.

Anarfi, J. K. and Jagare, S. (2005a). Towards the Sustainable Return of West African. Transnational Migrants: What are the Options? Paper presented at a conference on New Frontiers of Social Policy, Arusha, 12-15 December.

Anarfi, J. K., Kwankye, S. and Ahiadeke, C. (2005b). This is a Book Chapter. In Manuh, T (ed), At Home in the World? International Migration and Development in Contemporary Ghana and West Africa: Migration, Return and Impact in Ghana: A Comparative Study of Skilled and Unskilled Transnational Migrants ( ). Sub-Saharan Publishers: Accra.

Asiedu, B.A. (2010). Some Perspectives on the Migration of Skilled Professionals from Ghana, African Studies Review, 53(1), pp. 61-78.

Asiedu, B. A. (2005). Some Benefits of Return Visits to Ghana, Population, Space and Place, $11,1-11$.

Ba H. 2006. Les statistiques des travailleurs migrants en Afrique de 1"Ouest, Cahier des Migrations Internationales 79F, Bureau International du Travail, Genève, p. 80.

Black, R. and Gent, S. (2004). Defining, measuring and influencing sustainable return: the case of the Balkans, Working Paper T7, Research.7, Centre for Migration, University of Sussex.

Black R. and King, R. (2004). Editorial Introduction: Migration, Return and Development in West Africa, Population, Space and Place, 10, 75-83.

Black, R, King, R and Litchfield, J. (2003). Transnational Migration, Return and Development in West Africa. Final Research Report to DFID, Sussex: Sussex Centre for Migration Research, University of Sussex

Blitz, B., R. Sales and Marzano, L. (2005). Non-voluntary return? The politics of return to Afghanistan, Political Studies, 53 (1), 182-200. 
Cassarino, Jean-Peirre, (2004). Theorising Return Migration: A Revisited Conceptual Approach to Return Migrants. International Journal on Multicultural Societies, 6 (2), 253-279.

de Haas, H. (2003). Migration and development in southern Morocco: the disparate socioeconomic impacts of out-migration to the Todgha Oasis Valley (Unpublished Ph.D. thesis). Nijmegen: Radboud University.

Diko, I., and Tipple, C. (1992). Migrants build at home: Long distance housing development by Ghanaians in London. Cities, 1 (1), 288-94.

Hamann, V. (2000). Migration and Development: The investment of migrants in the high emigration area of Zacatcas, Mexico. Paper presented at the ISA Conference: International Migration in Latin America Enters a New Millennium, 2-4 November 2000, Buenos Aires.

Hart, D. M. 2006. From Brain Drain to Mutual Gain: Sharing the Benefits of High-Skilled Migration. Issues in Science and Technology (fall). Retrieved from www.issues.org.

International Organisation for Migrants (2009). Migration in Ghana: A Country Profile, Geneva: International Organization for Migration

International Organization for Migration (2003). World Migration 2003: Challenges and Responses for People on the Move. Geneva: International Organization for Migration.

Jackson, P., Crang, P. and Dwyer, C. (2004). This is a Book Chapter. In: Jackson, P., Crang, P. and Dwyer, C. (eds.), Transnational spaces: Introduction: the spaces of transnationality (pp.1-23). London: Routledge.

Kivisto, P. (2001). Theorizing transnational immigration: a critical review of current efforts, Ethnic and Racial Studies, 24 (4), 549-577.

Koser, K. and Black, R. (1999).This is a Book Chapter. In Black, R. and Koser, K. (eds), The end of the refugee cycle? Refugee repatriation and reconstruction: The end of the refugee cycle? (pp. 2-17). New York: Berghahn Books.

Kubat, D. (1981). The Politics of Return: International Return Migration in Europe, NewYork: Center for Migration Studies.

Levitt, P and Nyberg-Sørensen, N. (2004). The transnational turn in migration Studies, Global Migration Perspectives, 6, pp. 2-13.

Levitt, P. and Glick Schiller, N. (2004). Conceptualizing Simultaneity: A Transnational Social Field Perspective on Society. International Migration Review, 38(3), 1002-1039.

Lynn, Leonard and Salzman, Hal. (2006). Collaborative Advantage. Issues in Science and Technology (winter), pp.74-82 
Orozco, M. (2005). Transnational Engagement, Remittances and their Relationship to Development in Latin America and the Caribbean, Institute for the Study of International Migration, Washington: Georgetown University.

Nuro, E. A. (1999). Brain Drain from Ghana: Case of University Lecturers (Unpublished MPhil Thesis) Department of Geography and Tourism, University of Cape Coast: Cape Coast.

Smith, L. (2007). Tied to Migrants: Transnational Influences on the Economy of Accra, Ghana, Netherlands: African Studies Centre, Leiden.

Taylor, Linnet. (2009). Return Migrants in Ghana, Institute for Public Policy Research: London.

Thomas-Hope, E. 1999. Return Migration to Jamaica and its Development Potential, International Migration, 37(1), 183-207.

Tiemoko, R. 2004. Migration, return and socio-economic change in West Africa: The role of family, Population, Space and Place, 10, 155-174.

Vertovec, S. 2009. Transnationalism, London: Routledge. Wyman, M. (2005). This is a Book Chapter. In Harper, M. (ed.), Emigrants Homecomings: The Return Movement of Emigrants, 1600-2000: Emigrants returning: The evolution of a tradition (pp. 16-31), New York: Manchester University Press. 